\title{
Genetic Parameters of Body Weight from an Exotic Line of Duck in Vietnam
}

\author{
Thuy Thi LE, Tuyen Xuan DUONG, Keijiro NIRASAWA ${ }^{1)}$, \\ Hideaki TAKAHASHI"), Tsutomu FURUKAWA ${ }^{2)}$ \\ and Yoshitaka NAGAMINE ${ }^{1)}$ \\ National Institute of Animal Husbandry, Hanoi, Vietnam \\ 1) National Institute of Agrobiological Resources, Tsukuba-shi 305-8602 \\ 2) National Institute of Animal Industry, Tsukuba Norin Kenkyu Danchi, \\ Ibaraki-ken 305-0901
}

(Received August 12, 1997)

\begin{abstract}
The V 1 duck is a grandparent line of Cherry Valley Super Meat Duck which was bred in England. The V 1 duck was imported to Vietnam Institute of Animal Husbandry in 1991 and used for selection experiments. A total of 1040 records of V 1 duck raised in Vietnam were used to estimate genetic parameters and the genetic trend of body weight. Body weight at 8 and 24 weeks (BW 8 and BW 24) were measured through 4 generations. Best linear unbiased prediction method with an animal model and restricted maximum likelihood were applied to estimate breeding values and heritabilities, respectively. Means of BW 8 and BW 24 were 2,202 and 3,297 $\mathrm{g}$ for male and 2,168 and $3,071 \mathrm{~g}$ for fernale. Estimated heritabilities were 0.104 for BW 8 and 0.128 for BW 24, respectively. Genetic trends were not significant for either BW 8 or BW 24.
\end{abstract}

Anim. Sci. Technol. (Jpn.) 69 (2) : 123-125, 1998

Key words : Vietnam, Duck, Body weight, Heritability, Genetic trend

In Vietnam $80 \%$ of the population, 12 million households, are engaged in crop and animal production. Duck is very common livestock and they scavenge on fallen grains, insects and weeds in rice paddy field. Farm income has been reported based on rice and ducks ${ }^{5}$. The number of 140 million poultry are raised in Vietnam and 32 million, 23\%, are occupied by ducks. Cherry Valley Super Meat Duck (C.V Super M Duck ) originated from Cherry Valley Ltd. in England ${ }^{1)}$ and this strain is well known for its high producing performance. The V1 line is one of the grandparent lines of C.V Super M Duck, that was imported from England by Vietnamese National Institute of Animal Husbandry in 1991. A selection experiment was carried out from 1991 to 1995 and the objectives were as follows.

1) To investigate egg and meat production of $\mathrm{V} 1$ line using local feeds and in relation to the climate of Vietnam.

2) To increase the growth rate of $V 1$ line by selection.

In this paper, we report estimated genetic

ヴェトナムにおける外国系アヒルの体重に関する遗伀的パラメター：リ一トゥイシ・ッ゙オンズーツェン・

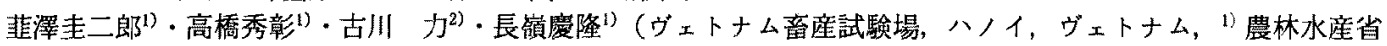
農業生物凟源研究所, つ〈ば市 305-8602，光農林水産省畜産試験場，茨城県筑波農林研究寺地 305-0901） 


\section{LE, DUONG, NIRASAWA, TAKAHASHI, FURUKAWA and NAGAMINE}

parameters and genetic trends on the growth rate from a 4 generation selection experiment.

\section{Materials and Methods}

Number of 1040 records of body weight at 8 weeks (BW 8) and 446 records of body weight at 24 weeks (BW 24) were observed from 1040 ducks of $\mathrm{V} 1$ line. These data were from a selection experiment to improve the growth rate of $\mathrm{V} 1$ duck. Selection was based on the individual performance of BW 8 . The top $5 \%$ of males and $20 \%$ of females were selected as parents for the next generation. During the experiment period ducks were fed concentrate from local feeds. All data were from a station of National Institute of Animal Husbandry in Vietnam.

Breeding values were estimated by best linear unbiased prediction method with an animal model ${ }^{2)}$. Heritabilities were estimated by restricted maximum likelihood ${ }^{3)}$. In the model, sex and generation effects were considered as fixed effects. Estimated sire breeding values were used to observe genetic trends. Sires' breeding values were weighted with progeny number in each generation and the average of weighted sires breeding values from each generation wete used as an indicator of genetic trend.

\section{Results and Discussion}

Numbers of observations, mean, standard de- viation, minimum and maximum values for the main traits are shown in Table 1 . Though males and females were reared under the same conditions, mean values of body weight of male were larger than female at 8 and 24 weeks, respectively. The means of $\mathrm{BW} 8,2,202 \mathrm{~g}$ for male and $2,168 \mathrm{~g}$ for fernale, were significantly different at the $5 \%$ level. The means of BW 24, $3,297 \mathrm{~g}$ for male and $3,071 \mathrm{~g}$ for female, were significantly different at the $1 \%$ level. Mean values of $\mathrm{BW} 8$ of the $\mathrm{V} 1$ line were $36.6-40.8 \%$ higher than Co duck, a Vietnamese native duck, at 8 weeks ${ }^{4}$. The target weight of V1 female duck was around 2,000 $\mathrm{g}$ for BW 8 and around 2,800 g for BW 24 in England ${ }^{1)}$. Means of BW 8 and BW 24 of V 1 female in Vietnam were larger than the target values. Though body weight records in Vietnam showed the high variation, for example, BW 8 for females ranged from 1,400 to $2,850 \mathrm{~g}$. It suggested some inequality in management or environmental conditions during the experiment.

The estimated heritabilities were only 0.104 for BW 8 and 0.128 for BW 24. Variance of breeding values and residual for $\mathrm{BW} 8$ were 5,526 and 47,516, respectively. These values were 7,266 and 49,688 for BW 24 , respectively. Pingel ${ }^{6)}$ listed the heritabilities of body weight from Muscovy duck and Pekin duck. He reported the heritabilities from 0.43 to 0.53 for Muscovy ducks and from 0,23 to 0.89 for Pekin ducks. The estimated heritabilities, 0.104 and

Table 1. Basic statistics of growth traits

\begin{tabular}{llllll}
\hline Traits & $\mathrm{N}$ & Mean & $\mathrm{SD}$ & Minimum & Maximum \\
\hline $\begin{array}{l}\text { Male : } \\
\text { Body weight at : }\end{array}$ & & & & & \\
$\quad 8$ weeks $(\mathrm{g})$ & 437 & 2,202 & 239 & 1,450 & 2,900 \\
$\quad 24$ weeks $(\mathrm{g})$ & 115 & 3,297 & 264 & 2,600 & 4,100 \\
Female : & & & & & \\
Body weight at: & 603 & 2,168 & 228 & 1,400 & 2,850 \\
8 weeks $(\mathrm{g})$ & 331 & 3,071 & 245 & 2,400 & 3,700 \\
24 weeks $(\mathrm{g})$ & & & & & \\
\hline
\end{tabular}

$\mathrm{N}$ : Number of records SD : Standard deviation 
0.128 , for $V 1$ duck were lower than those from other breeds.

Since wide range of body weight was observed, lower heritabiliteis might be caused by heterogeneous or unsuitable conditions. Group feeding, for example, often causes bias in the food supply. Severe climate, such as high temperature and humidity, can influence the estimate of heritability. High temperature and humid environmental condition in Vietnam might work as disturbance to express the original genetic potential.

The genetic trends of body weight through 4 generations were examined. Genetic improvements were around $+16 \mathrm{~g}$ for $\mathrm{BW} 8$ and $+26 \mathrm{~g}$ for BW 24 from generation 1 to 4 . However, a positive genetic trend was observed for BW 8 and BW 24, their improvements were relatively small and were not significant. Genetic improvement of $\mathrm{BW} 8,16 \mathrm{~g}$, was only $0.7 \%$ of mean, $2,202 \mathrm{~g}$, for male. Since heritabilities for BW 8 and BW 24 were only around 0.1 , it was hard to expect large genetic improvement. Environmental conditions should be considered again to clarify the genetic performance of Individual and it could increase the heritability.

Only the growth rate was targeted to improve in this selection experiment. Though egg yield traits as well as body weight are important in duck breeding. After accumulat- ing the data, genetic parameter for egg production with growth traits should be estimated together under a multiple traits model.

\section{References}

1) Duong XT, Nguyen CQ, Nguyen VD, Le TT. Study on establishment of system for breeding and rearing of C.V super M. duck breed in Vietnam. Scientific and technological journal of National Institute of Animal Husbandry (Vietnam), 160-166. 1992.

2) Groeneveld E, Kovac M, Wang T. PEST a general purpose BLUP package for multivariate prediction and estimation. Proceedings of 4 th world congress on genetics applied to livestock production, $13: 488-491.1990$.

3) Groeneveld E. VCE a multivariate multimodel REML (co) variance component estimation package. Proceedings of 5th world congress on genetics applied to livestock production, $22: 47-48.1994$.

4) Le XD. Conservation Genetic Resource on Co Duck. On the results of livestock genetic conservation in Vietnam. 93-101. Agricultural publishing house. Hanoi. 1994.

5) Nguyen $T$, Nguyen $C N$, Duong XD, Sasaki M. Rice-fish-duck-pig production system in Vietnam. Integrated systems of animal production in the Asian region. Proc. 8th AAAP Anim. Sci. Cong., 1 : 333-346. 1996.

6) Pingel H. Genetic of Growth and meat production in waterfowl. In : Poultry Breeding and Genetics. (Crawford RD eds.) 691-704. Elsevier. Amsterdam. 1990. 